DOI: 10.19195/0137-1150.163.41

\author{
ANNA GAWARECKA \\ Uniwersytet im. Adama Mickiewicza w Poznaniu, Polska \\ gawarecka@gazeta.pl
}

\title{
Między nobilitacją a deprecjacją. \\ Ideologiczne kody postrzegania starości w dziewiętnastowiecznej literaturze czeskiej (przypadek Karla Václava Raisa)
}

S vráskami v tváři povadlé usedla si tam smutná paní a psala prstem v zadumání do rosy na opéradle.

Pak s troškou sebevédomi rekla si náhle: Vždyt’už chvátám, a štastné páry míjela tam, libajici se pod stromy.

A jeji šat už nešustí, už dotančila. A ret páli slzami, které líbávali dřive ji muži nad ústy.

Vždyt' přichází již z daleka a jenom málo dní je před ní. Vlastně už čeká na poslední, vlastně už na nic nečeká ${ }^{1}$.

Strofy te pochodzą z poematu Jaroslava Seiferta Píseň o Viktorce, utworu, który w momencie swego wydania (1950) wzbudził kontrowersje wśród cenzorów i decydentów polityki kulturalnej, zbyt daleko bowiem odbiegał od obowią-

${ }^{1}$ J. Seifert, Ruce Venušiny (výbor z poezie), Praha 1998, s. 297. 
zujących wówczas marksistowsko-stalinowskich dyrektyw interpretacyjnych. Ich bohaterką jest Božena Němcová, najwybitniejsza czeska pisarka XIX wieku, postrzegana przez kolejne generacje recenzentów i badaczy jako swego rodzaju symbol czeskości i jednocześnie - co wyraźnie widać w dzisiejszej refleksji literaturoznawczej - prekursorka écriture féminine ${ }^{2}$. W latach pięćdziesiątych, na prawach niepodważalnego aksjomatu, panowała jednak wyłącznie polityczno-społeczna wykładnia jej twórczości, najtrafniej być może zdefiniowana w tytule broszury Juliusa Fučíka Božena Němcová bojujici (1940), przypisująca pisarce lewicowe, by nie powiedzieć - protokomunistyczne, poglądy. Seifert, który odważył się przełamać ów obligatoryjny ideologiczny kod spoglądania na spuściznę autorki Babički (1856) i skoncentrować uwagę wokół jej kobiecości, pojmowanej na tyle wąsko, że tracącej w wyniku procesu przemijania rację bytu, naraził się w konsekwencji na bezpardonowe ataki ze strony „prawomyślnych” egzegetów ${ }^{3}$. Niezależnie bowiem od tego, że wyprzedził dzisiejsze postrzeganie pisarstwa i osoby Němcovej, eksponujące feministyczne czy genderowe aspekty nie tyle zresztą twórczości, co autentycznej — znanej przede wszystkim z korespondencji - biografii prozaiczki, jego ujęcie zaskakuje radykalnym przewartościowaniem dotychczasowych odczytań. Zaskakuje zaś tym bardziej, że to właśnie Němcová (dzięki autorytetowi jej najważniejszej powieści Babička) w potocznej świadomości odbiorców jawi się jako apologetka kobiecego wieku podeszłego postrzeganego w kategoriach skarbnicy życiowego doświadczenia, czyniącego zeń przestrzeń aksjologicznego oddziaływania, które promieniuje swym wpływem na wszystkie płaszczyzny funkcjonowania zbiorowości ${ }^{4}$. Wyraziste, choć pochodzące raczej z lektury apriorycznie zaprogramowanej przez ideologiczne kody Odrodzenia Narodowego niż z semantyki samego tekstu, powiązanie postaci babuni z mitem narodowym i uczynienie z niej jednej z najważniejszych figur czeskości osłabia w efekcie, ale nie eliminuje całkowicie melancholijnego czy pesymistycznego spojrzenia na towarzyszący upływowi lat zanik sił witalnych

${ }^{2}$ Por. M. Filipowicz, Urodzić naród. Z problematyki czeskiej i słowackiej literatury kobiecej II połowy XIX wieku, Warszawa 2008, s. 89-101.

${ }^{3}$ Por. M. Bauer, Souvislosti labyrintu. Kodifikace ideologicko-estetické normy v české literatuř 50. let 20. století, Praha 2009, s. 209-211.

${ }^{4}$ Němcová, kreując postać babuni, zdaje się poniekąd wyprzedzać poglądy dzisiejszych badaczy z kręgu Women's Studies, twierdzących, że: „Kontakt z kobietą-staruchą jest niezbędny zwłaszcza tym, które pragną tworzyć. Kobieca kreacja bywa utożsamiana z magią, korzystaniem z sił nadprzyrodzonych, byciem wtajemniczoną w jakieś misteria i prawdy. Wtajemniczenie adeptki może się odbyć jedynie za pośrednictwem medium — dojrzałej, doświadczonej wiedźmy. Stare kobiety są skarbnicą duchowości, opiekują się rytuałami. [...] Kobiety spędzają ze sobą dużo czasu i wspólnie wykonują codzienne czynności [...]. Wiele sytuacji, w których biorą udział [...] ma charakter inicjacyjny, przy czym starsza jest przewodniczką, młodsza - adeptką". (G. Dragun, „Chcę być stara, dojrzała kobieta”. Afirmacja dojrzałości w prozie Izabeli Filipiak i Olgi Tokarczuk, [w:] Egzystencjalne doświadczenie starości w literaturze, red. A. Gleń, I. Jokiel, M. Szladowski, Opole 2008, s. 102). 
(wystarczy przypomnieć sobie ostatnie dni życia bohaterki), rekompensuje je jednak wyeksponowaniem pozytywnych aspektów schyłku egzystencji.

Dla późniejszych reprezentacji figury starości w dziewiętnastowiecznej literaturze czeskiej, szczególnie zaś jej linii czerpiącej swój materiał tematyczny ze środowiska ludowego, ujęcie Němcovej odegrało rolę inspiratywną, by nie powiedzieć — kanoniczną. Niekłamany autorytet autorki, wzmocniony powszechnie dzielonym przeświadczeniem o arcydzielności jej najważniejszej powieści, obligował niejako twórców sięgających po tematykę wiejską do intertekstualnego ustosunkowania się - najczęściej w aprobatywnym czy alegacyjnym duchu do sławnego pierwowzoru. Dopiero w ostatnich dekadach stulecia - pod naporem naturalistycznych inspiracji - model ten został częściowo zakwestionowany, a obraz wsi - dotychczas traktowanej jako matecznik i ostoja czeskiego etosu narodowego - do pewnego stopnia utracił swój wyidealizowany charakter. Nadal jednak zakodowana w zbiorowej świadomości kulturowa pamięć o modelowym statusie Babički stanowiła istotną płaszczyznę odniesienia, wytyczającą horyzont oczekiwań czytelników poszukujących podczas lektury potwierdzenia z góry przyjętych założeń recepcyjnych. W efekcie w literaturze tej, nawet operującej ciemnymi barwami „zolowsko-biologicznej” antropologii i eksponującej nieludzkość czy degenerację stosunków interpersonalnych, rozbicie jedności wspólnot wiejskich postrzega się w kategoriach demontażu tradycyjnej przestrzeni aksjologicznej, spowodowanego otwarciem się wsi na wpływy nowoczesnej cywilizacji, a symbolicznym depozytariuszem owych wartości utraconych w wyniku ingerencji wpływów zewnętrznego świata bywa - na prawach swoistej oczywistości - stary gospodarz.

Dodatkowo sytuację, charakterystyczną dla całego obszaru europejskich przemian kulturowych, a więc znajdującą swe odzwierciedlenie również w Czechach, komplikują, jak pisze Agnieszka Czyżak:

Wyraźne u schyłku wieku sygnały narastającego kryzysu kultury i nasilającego się pesymizmu, wiązane z rozmaicie pojmowanym modernizmem, zachwiały ustabilizowanym porządkiem pojęć i ich literackich przedstawień. Bunt przeciw ideałom wcześniejszej epoki zaowocował między innymi odrzuceniem starości uznanej jako znak tego, co minione. Oczywistym okazał się powrót do romantycznego ideału młodości, jednak w nowych zrewaloryzowanych wariantach. W opozycji starości i młodości odnaleźć można symboliczne ujęcie walki między odrzucanymi, zmurszałymi regułami a ideałami nowoczesności wcielanymi w życie przez nowych ludzi. „Stary” mogło więc znaczyć po prostu nie-młody i przynależący do starego porządku 5 .

W tak zakreślonym kontekście historycznym i kulturowym Josef Václav Rais, prozaik nieunikający skądinąd $\mathrm{w}$ swej twórczości korzystania $\mathrm{z}$ inspiracji naturalistycznych, zdecydował się opublikować powieść Pantáta Bezoušek (1894) opowiadającą o wizycie tytułowego bohatera „výminkaře z Nové vsi pod Zvičinou", czyli — używając dzisiejszych pojęć — rolnika, który przekazał swe

${ }^{5}$ A. Czyżak, Starość i literatura - strategie wykluczenia, [w:] Dwudziestowieczność, red. M. Dąbrowski, T. Wójcik, Warszawa 2004, s. 290. 
gospodarstwo dzieciom, u syna — znanego praskiego adwokata szczęśliwie ożenionego z córką miejskiego patrycjusza. Perypetie protagonisty z trudem odnajdującego się w wielkomiejskich realiach czeskiej stolicy, częściowo prezentowane w konwencji komicznej, częściowo natomiast — sentymentalnej, choć niewątpliwie przyciągają uwagę czytelnika i w swoim czasie - dzięki narracyjnej atrakcyjności — pozwoliły dziełu uzyskać status bestsellera, z samego zaś Bezouška uczyniły jedną z symbolicznych figur czeskiej wyobraźni zbiorowej, schodzą tu jednak na plan dalszy, zważywszy, że za pośrednictwem tej popularnej w gruncie rzeczy fabuły pisarz przemyca bardzo poważne refleksje dotyczące podstaw czeskości i projektów pożądanego modelu życia narodowego. Jak bowiem przypomina Vladimír Štěpánek:

Skutečnost, že zachovalý český venkov byl v obrozenské době pramenem obrody, že se stal základem novodobé národní společnosti, vedla $\mathrm{k}$ široce rozšířenému přesvědčení, že venkovský lid nejen byl, ale je a nadále — i v nové průmyslové době — bude jádrem národa, zárukou jeho existence. [...] Úloha, kterou venkov sehrál za obrození, poskytla pak také ony obrodné a útěšné ideje, jež se hledaly a konstruovaly v době Raisova Bezouška. Hodnoty starého venkova, zdálo se, mohly by pomoci k ozdravení pokaženého venkova, pomoci ohroženému národu. [...] Věkem starý a mravem, názorem starosvětský venkovan jako titulní a centrální hrdina je zajisté velmi důraznou, velmi účinnou formou románového ztvárnění této ideje ${ }^{6}$.

Štěpánek w swych dalszych wywodach stara się co prawda udowodnić, że ten pozornie oczywisty klucz interpretacyjny nie znajduje w pełni miarodajnego potwierdzenia w sekwencji powieściowych wydarzeń, ale jego teza podkreślająca trwałość odrodzeniowego mitu (czy raczej fantazmatu) wiejskiego ludu, która pozwala na nawiązanie natychmiastowego i niewymagającego uzasadnień porozumienia z czytelnikiem, niewątpliwie pozostaje tu w mocy. Niezależnie bowiem od wszelkich zastrzeżeń i - zdeterminowanych realistyczną konwencją autorskiej metody twórczej — modyfikacji Pantáta Bezoušek mieści się wewnątrz budzicielskich tradycji, które bazowały na nobilitacji czy nawet sakralizacji idealizowanej — w sensie krajobrazowym i aksjologicznym — przestrzeni ludowości. Zabiegi nobilitacyjne i sakralizacyjne korespondują w tym przypadku zaś z przeświadczeniem, że: „Národ český se představoval jako »národ chaloupky« se vším, co $\mathrm{k}$ tomu přináleželo: jako národ spjatý $\mathrm{s}$ idylickým nedějinným prostorem, s ideálem rolnické práce, ale i s ideálem duchovní práce kulturní, které chaloupka metaforizovala jako místo udržení kontinuity české řeči, písemnictví, osvěty" ". Rais ten głęboko w czeskiej świadomości zbiorowej utrwalony mit podtrzymuje jednak tylko do pewnego stopnia. Wizyta Bezouška w Pradze nie przebiega bowiem bezkonfliktowo, a jego przemyślenia towarzyszące odkrywaniu rozmaitych płaszczyzn stołecznego życia rzadko stanowią wyraz entuzjazmu dla majestatu „królowej miast”. Już pierwszy kontakt bohatera z praską przestrzenią

${ }^{6}$ V. Štěpánek, Karel Václav Rais, [w:] K.V. Rais, Pantáta Bezoušek, Praha 1981, s. 9-10.

${ }^{7}$ V. Macura, Chaloupka - projekt idyly, [w:] Poetika mist, red. D. Hodrová, Praha 1997, s. 57. 
architektoniczną budzi w nim raczej przerażenie niż zachwyt, a to wstępne, rodzące niepokój i często nawet niechęć w stosunku do zurbanizowanego świata wrażenie nie mija przy bliższym poznaniu praskiej rzeczywistości ${ }^{8}$.

Bezoušek do końca pozostaje jej krytycznym obserwatorem, a cała powieściowa geografia kulturowa zasadza się na przeciwstawianiu oswojonej przestrzeni wiejskiej nowo poznawanym — obarczonym rozmaitymi mankamentami - realiom miasta:

No, ta vaše Praha vypadá, když prší! A ti Pražáci chodí jako urousané slepice, kapky se to bojí. To jsou naši lidé jinačí, nenosí pořád tu bouřku, ale pomyslí si: No, promoknu-li, promoknu, však ono to uschne. Panbůh rač chránit, aby na Prahu měly přijít nějaké rány; co by ti lidé dělali, když čistý deštíček je takhle sebere! ${ }^{9}$

Część z przywoływanych refleksji bohatera służy w powieści pełnemu sympatii i pobłażliwemu, ale zarazem jawnie żartobliwemu spojrzeniu na starego wieśniaka, większość jednak wpisuje się w toczoną tu podskórnie debatę między dwoma rudymentarnymi składnikami czeskiej odrodzeniowej mitologii, a mianowicie między mitem Pragi jako symbolu wielkiej i heroicznej historii narodowej a mitem wsi postrzeganej w kategoriach współczesnego dziedzica podstawowych wyznaczników autochtonicznej tradycji. Pierwotnie — w zintegrowanym projekcie budzicielskim oba te składniki funkcjonowały na zasadzie koherencji — jako w pełni uzgodnione ze sobą komponenty jednego zespołu ideowo-interpretacyjnego, ale w miarę upływu czasu - wraz ze związaną ze wzbogacaniem przestrzeni czeskiego życia kulturowego dywersyfikacją poszczególnych elementów narodowego mitu - jego skorelowane wcześniej płaszczyzny zaczęły wykazywać nie tylko swe odrębności, ale nawet - biorąc pod uwagę radykalizm szybko następujących przemian społecznych i obyczajowych — jednoznacznie proklamowane skontrastowanie ${ }^{10}$. Rais rejestruje zatem ten etap demontażu odrodzeniowej

${ }^{8}$ Por. „Pantáta se spíše zhrozil než aby se byl obdivoval. Celé divné kamenné město, s ohromnou tmavou věží a množstvím drobných věžiček uprostřed, zdvíhalo se tam k čisté obloze, jako by ve vzduchu viselo. [...] Po chwilce přikrčen hleděl k oknu protejšímu; v dáli stál vrch s černým lesem na temeni a pod ním až sem k vlaku byly domy, zřetelné, veliké kamenné domy, z nich vyčuhovaly začmoudlé komíny. Ted' mezi domy spatřil lesklý, místy sršící, hladce rozestřený pás široké řeky; tvořila překrásný, svítící,obloukovitý lem, na němž se temněly lod'ky a vory. Ale tam, na druhém břehu letěl vlak, živý, funící vlak, po mostě zas jiný uháněl a kolem dokola samé domy, vyšší, světlé, tmavé". K.V. Rais, op. cit., s. 34-35.

${ }^{9}$ Ibidem, s. 144.

${ }^{10} \mathrm{Na}$ aporyczność, niejako od początku podkopującą uspójnienie narodowego mitu, zwrócił też uwagę Josef Jedlička, przypominając, że w odrodzeniowej literaturze, co może zaskakiwać, czeski rolnik pojawia się raczej sporadycznie. Badacz odkrycie to uzasadnia tezą, że rolnik ów: „Literárním hrdinou se mohl stát teprve potom, když se obrození dovršilo, když se obecné národní vědomí ustálilo a když historická realita už nemohla být prakticky — to jest politicky a kulturně — nebezpečná historickému mýtu. Nebot' patriarchální češství [...] je ve své poněkud těžkopádné srostitosti pravý opak všeho pokrokářství, vši radikalistické činorodosti — to jest protiklad toho, čím politicky žilo české národní obrození a co se na počátku století začalo stávat politickým programem moderního sociálního hnutí”. J. Jedlička, České typy a jiné eseje, Praha 2009, s. 39. 
wyobraźni symbolicznej, w której początkowa - bezwarunkowo powszechnie akceptowana i uznawana za kwintesencję czeskości — symbioza miasta i wsi wykazuje swe niemożliwe do przezwyciężenia antynomie i zaczyna uwzględniać rzeczywiste konflikty rozwarstwiające czeską wspólnotę, wcześniej — w rozważaniach budzicieli — stanowiącą nierozłączną i monolityczną całość ${ }^{11}$. Innymi słowy, pisarz, prowadząc skomplikowaną i wielowektorową grę z narodową mitologią, z jednej strony podtrzymuje jej aktualność, z drugiej zaś przygląda się jej okiem realisty. Widać to nie tylko w powieściowej prezentacji wsi, przywoływanej zresztą najczęściej za pośrednictwem wspomnień protagonisty, lecz także, być może nawet przede wszystkim, w obrazie Pragi, która, jak dowodzi Vladimír Macura,

je [...] v klasické obrozenské podobě pojatá jako „minulá sláva”, at’ již je představována jmény slavných historických a mytologických postav [...], nebo ve vnější tvářnosti materializována (historické stavby) či konečně vnější tvářností města pouze označovaná: přítomná Praha jako konvenční zcela arbitrérní, tj. toliko o konvence dobového úzu se opírající znak minulosti ${ }^{12}$.

Taką właśnie Pragę, ujmowaną jako, ,ideologické fikční okoli”"13, prezentują Bezouškowi członkowie jego rodziny, próbując wtłoczyć go w zaprogramowaną przez vlastenecką tradycję rolę nostalgiczno-patriotycznego turysty. On sam woli jednak przyglądać się współczesnej miejskiej egzystencji, w jej pośpiechu, hałasie, anonimowości, wyobcowaniu relacji międzyludzkich czy szarości stłoczonych kamienic nie znajdując dla siebie żadnych de facto enklaw zakorzenienia. Jego jednoznacznie deklarowane przeciwstawienie miasta rodzimej wsi, odczuwanej jako przestrzeń własna i przede wszystkim opatrzona dodatnim znakiem wartościowania, przywołuje — na zasadzie jasnych sygnałów skojarzeniowych - cały paradygmat odrodzeniowej idealizacji ludowości:

Pantáta stoje před oknem, ruce měl sepjaty a modlil se Anděl Páně. Potom vzpomínal na domácí podvěčerní kraj; bylo mu jako by stál v polích na mezi a zíral šírem, halícím se v šero. Všude ticho, svato, jen jemný věterek šepotá, jako by země oddychovala. Ted' zazněl zvon v bílé věži kostelní, a klidně, vážně hlaholí tmavým krajem. K němu se přidávají i menší zvonky kostelních vížek - lánský vysokým hláskem pláče, brtevský jednotvárně jako dvě kladiva do kovadliny úsečně klinká, chotečské zvony se jen chvílemi v tichém vánku ozvou. A pantáta stojí na mezi, poslouchá a tiše se modlí...14

W praskim świecie bohater odgrywa w rezultacie rolę Innego — przybysza z odmiennej rzeczywistości, szanowanej niewątpliwie, ale traktowanej z pełnym zaciekawienia dystansem. Nie należy bowiem zapominać, że w dziewiętnastowiecznej czeskiej zbiorowej wyobraźni ścierały się dwa częściowo odrębne,

11 V. Macura, Český sen, Praha 1998, s. 54-62.

12 V. Macura, Znamení zrodu. České národni obrození jako kulturní typ, Jinočany 1995, s. 183.

13 Por. B. Fořt, Fikční světy české realistické prózy, Praha 2014, s. 105-106.

${ }^{14}$ K.V. Rais, op. cit., s. 92. 
częściowo zaś komplementarne sposoby postrzegania wsi. Jak bowiem pisze Jiří Rak:

Pro osvícenské generace byl venkovský lid objektem pedagogického a filantropického působení. [...] Brzy ale i česká společnost začala snít svůj sen o ztraceném ráji, který situovala právě na venkov a osídlila si jej svými vlastními „urozenými divochy”. Idealizace klidného venkovského života jako protikladu rušného města ovšem odpovídala i duchu biedermeierského životního stylu. Jde samozřejmě o pohled měšt’ana, který na venkov zavítá ve chvili volna a rozplývá se nad jeho údajnou idylou, aby se posléze s úlevou vrátil ke svému městskému pohodlí. [...] Stejným způsobem jako krajinu si vlastenci idealizovali i venkovský život. V očích biedemeierského měštana představovala vesnice v protikladu k městu (které ovšem trvale opustit nezamýšlel) obraz št’astného života v souladu s př́rodou. Byl to venkov nahlížený očima nedělních výletníků, kde venkované hráli roli rázovité štafáže krajinných scenérií. Vlastenci prostě cestovali za městské hradby jako do skanzenu, kde chtěli pozorovat ten obraz vesnické idyly, který si sami vysnili ${ }^{15}$.

Umieszczenie figury wiejskiego starca $\mathrm{w}$ centrum społecznej i architektonicznej przestrzeni miasta pozwala Raisowi oba te modele imaginacyjne do pewnego stopnia zdemaskować, obnażając ich stereotypowy charakter i sztuczność przefiltrowaną przez pryzmat rousseauowskiej sentymentalnej konwencji ${ }^{16}$. W postaci Bezouška pisarz odnajduje co prawda komponenty wzorcowej biografii zaprojektowanej zarówno wewnątrz czeskiego/odrodzeniowego kodu antropologicznego, jak i europejskiego kodu arkadyjskiego, ale ukazuje też, że oba te typy kulturowego dyskursu ani nie wzbudzają w bohaterze pełnego zrozumienia, ani tym bardziej protagonista się z nimi nie utożsamia. Na obejrzenie na scenie Teatru Narodowego przedstawienia Strakonického dudáka Josefa Kajetána Tyla, czyli jednego z najbardziej kanonicznych przykładów odrodzeniowej mityzacji wsi, reaguje raczej ambiwalentnymi uczuciami, w niewinnej, przeznaczonej dla młodego widza baśni dramatycznej dostrzega bowiem elementy deprawujące dzieci (konkretnie nie podobają mu się występy zbyt śmiało, jego zdaniem, roznegliżowanych baletnic ${ }^{17}$ ), a sztampowe uwagi synowskiego teścia wychwalające uroki wiejskiej przyrody kwituje sarkastycznym niemal (i bliźniaczo przypominającym wcześniej cytowane uwagi Raka) opisem realnych uwarunkowań rolniczego losu:

15 J. Rak, Exotismus doma aneb venkov versus město, [w:] Cizí, jiné, exotické v české kultuře 19. století, red. K. Bláhová, V. Petrbok, Praha 2008, s. 222-223.

16 Por.: „Venkovský člověk české obrozenské literatury býval většinou střižen podle ustáleného romantického receptu. At' už jej autor vybavil větším či menším množstvím osobitých a životních rysů a dal mu svým nadáním větší či menší uměleckou úroveň, býval to téměř bez výjimky rousseauovský »nevinný divoch «, popřípadě herderovský »lid« o sobě”. J. Jedlička, op. cit., s. 38.

17 Por.: „Načesané ověnčené tanečnice byly př́ičinou, že se počal modlit, ačkoli už prve všecky své modlitby přeříkal; ale i těmi zbožnými myšlenkami se mu proplétaly celé chumáče tenkých, dlouhých noh, jež se kroutily jako gumové. [...] Rozehřát, s hlavou hučící, chrul se a převaloval v horkých peřinách, a v duchu huboval, nač mu ted', na stará kolena, je všech těch starostí a mrzutostí potřeba, nač se má tím vším trápit, proč do té Prahy jezdil a nezůstal radší doma u kamen! K.V. Rais, op. cit., s. 142. 
Milý pantáto, račte být tak laskáv, ale my už jsme tak starosvětští, že takovým slávným řečem ani kale nerozumíme - vždyt' dření je moc! Ano, páni z města si mohou přiběhnouti ven, chodit jen po procházkách a jen koukat, jak se říká, Pánubohu do oken, točit se vprávo, vlevo po polích a těšit se - jim na ourodě nezáleží, vidí na tom jen tu krásu, ale my v tom máme taky živobytí1 ${ }^{18}$.

Nie oznacza to jednak, że postać Bezouška ze swym — standardowym można by powiedzieć - wyposażeniem charakterologicznym i tożsamościowym pozostaje w Raisowskiej powieści przedmiotem krytycznego spojrzenia i że pisarz w konstruowaniu jego wizerunku nie stosuje chwytów idealizacyjnych, znanych $\mathrm{z}$ literackich reprezentacji wieku starczego ${ }^{19}$. Tyle tylko, że mowa tu o tradycji nieco odmiennej, choć często wieloma nićmi powiązanej z patriotyczno-idyllicznym dyskursem, a mianowicie o tradycji portretowania figury dziadka w dziewiętnastowiecznej prozie dla młodzieży, w której, jak pisze Jolanta Ługowska:

Dziadek [...] okaże się [...] jedną z najważniejszych postaci, jakim powierzona jest troska o właściwe wychowanie i właściwą edukację młodego pokolenia. Głęboko wrośnięta w realia życia rodzinnego [...] szybko staje się więc figurą konwencjonalną, elementem fikcji literackiej, a także swoistym dysponentem reguł sprawnego i przekonywającego przemawiania z intencją pouczenia i moralnego wzbogacenia odbiorcy. [...] Dziadek [...] jest ponadto swoistym zaprzeczeniem starości zniedołężniałej. Zachowując pełnię władz umysłowych, dysponuje on również znaczną sprawnością fizyczną, zdolny jest do podejmowania wysiłku związanego z edukacyjnymi przechadzkami i dalszymi nawet wyprawami, a wówczas „na gorąco” komentuje i objaśnia zdarzenia, których świadkami stają się towarzyszące mu dzieci $^{20}$.

Już wstępna, obligatoryjna niejako dla realistycznego mimetyzmu, deskrypcja zewnętrznego wyglądu Bezouška eksponuje (choć pisarz w tym opisie nie eliminuje całkowicie znaków fizycznej degradacji związanej z procesem starzenia ${ }^{21}$ ) owo wymagane od literackiej postaci dziadka-wychowawcy młodzieży zdrowie

18 Ibidem, s. 155.

${ }^{19}$ Bezoušek odgrywa zatem w Raisowskiej rzeczywistości rolę starca-mędrca zagubionego w labiryncie świata, a zatem bohatera, który, jak ukazuje Agnieszka Czyżak, ,jest podwójnie samotny - jako ten, kto błądzi po wrogiej przestrzeni, i ten, który samotnie przygotowuje się na nadejście śmierci. Ale bywa i tym, który — dzięki swej pozbawionej złudzeń mądrości, gorzkiej samowiedzy i umiejętności zachowania dystansu wobec spraw ziemskich — jest zdolny ująć w słowa nowe egzystencjalne doświadczenia. Wybór figury starca w labiryncie okazywał się więc swoistym wytrychem, pozwalającym ominąć coraz bardziej niewygodne i spełniane z coraz większą niechęcią społeczne zapotrzebowanie na mit zbiorowy”. A. Czyżak, Na starość. Szkice o literaturze przełomu tysiacleci, Poznań 2011, s. 69.

20 J. Ługowska, ,Dziadunio” jako figura nadawcy i rola narracyjna w literaturze przeznaczonej dla młodego odbiorcy, [w:] Egzystencjalne doświadczenie starości..., s. 255.

${ }^{21}$ Por.: „Byl malý, ale ramenáč, taková zámora zdravá. Černá očka, v jejichž koutcích byly celé vějiřky vrásek, jen se mu pod dlouhým prošedlým obočím kmitala; nad nízkým rozbrázděným čelem seděla mu kulatá huňačka, posazená poněkud do týla, a kolem ní se ploužily husté, popelavé proudy vlasů. Bradu měl úzkou, poněkud vyčuhlou, protože něměl zubů, a bledé, úzké rty mu zapadaly do úst; kulatý nos, na konci začervenalý, čtveracky seděl na zardělých tváŕích, plných drobných vrásek”. K.V. Rais, op. cit., s. 16. 
fizyczne, a stopniowe - eksplicytne i implicytne - dopełnianie i wzbogacanie tego wizerunku dowodzi również, że bohater zachował konieczną w takich przypadkach ,pełnię władz umysłowych”. Dzięki niej może spełniać przypisane w konwencjach literackich funkcje nauczyciela, doradcy i dobrego ducha całej rodziny, bez zastrzeżeń respektującej jego — eksponowaną w powieści — pozycję depozytariusza życiowej mądrości, płynącej z jednej strony z nagromadzonego w przebiegu długiej egzystencji bagażu doświadczeń, z drugiej zaś ze zinterioryzowanych i w praktyce biograficznej konsekwentnie urzeczywistnianych norm etycznych, płynących zarówno z głęboko przeżywanej wiary chrześcijańskiej, jak i z wrośnięcia we wspólnotę wiejską rządzącą się „odwiecznym” i zyskującym wymiar niemal absolutny, jak się wówczas apologetom czeskiego ludu wydawało, etosem. Mądrość ta czyni z późnego wieku pożądany powszechnie etap życia, postrzegana bowiem bywa jako naturalny atrybut starości. Podobnie zresztą jak pamięć, która dla starca jest, jak dowodzi Michał Kaczmarek,

najbardziej intymnym i drogocennym skarbem dla niego samego w planie indywidualnym. Ale skarbiec starczej pamięci może być nie mniej ceniony w wymiarze społecznym i kulturowym. Pamięć ludzi starych we współczesnych społeczeństwach oczywiście nie spełnia już tak doniosłej roli, jaką pełniła w społecznościach i kulturach niepiśmiennych. Była ona najważniejszą i właściwie jedyną przechowalnią treści wspólnych i doniosłych dla danej kultury i społeczności, pamięcią wspierającą się na autorytecie starego człowieka, który z racji wieku zazwyczaj widział, słyszał, wiedział i pamiętał najlepiej. [...] W kulturach niepiśmiennych, wobec braku innych środków przechowywania i gromadzenia istotnych treści kulturowych [...], bogactwo starczej pamięci powodowało, iż pamięć starca stawała się wartością wspólną dla całej społeczności ${ }^{22}$.

Uwagi te zostały oczywiście sformułowane z dzisiejszej perspektywy i odnoszą się do rzeczywistości kulturowej, w której starość bywa najczęściej ukrywana, deprecjonowana i spychana w przestrzeń społecznego wykluczenia ${ }^{23}$. Nie do końca też wypada traktować Bezouška jako przedstawiciela kultury niepiśmiennej, bohater nie jest bowiem analfabetą, choć jasno przyznaje, że czytanie gazet go nudzi, a jedyną „lekturą z wyboru” pozostaje dla niego modlitewnik. Niechęć ta

wydaje się charakterystyczna dla tego typu kultury, która - używając terminologii Waltera J. Onga - wprawdzie już zinterioryzowała pismo, ale zachowała jeszcze znaczne residuum oralne, co wyraża się m.in. w szczególnym społecznym zaufaniu do mądrości żywej, płynącej z osobistego doświadczenia, a także z licznych kontaktów face to face z innymi ludźmi

${ }^{22}$ M. Kaczmarek, O dobrodziejstwach pamięci starego człowieka. Oblicza starczej pamięci w wybranych tekstach literackich, [w:] Egzystencjalne doświadczenie starości..., s. 158, 160.

${ }^{23}$ Jak bowiem sądzi Agnieszka Czyżak, druga wojna światowa ostatecznie przyczyniła się do tego, iż „rozpad wspólnoty, która straciła wszelkie hierarchie wartości, sprawił, że starość ostatecznie przestała budzić szacunek, troskę, zrozumienie czy wdzięczność, gdyż zmieniła się przede wszystkim w synonim słabości i przestała się kojarzyć z godną podziwu umiejętnością rozumienia świata - świat stał się niepojęty i niemożliwy do uporządkowania, zwłaszcza dla starych ludzi”. A. Czyżak, Starość i literatura ..., s. 292. 
— zwłaszcza z tymi starszymi od siebie, a w związku z tym dysponującymi większym od mówiącego zasobem wiedzy tradycyjnej ${ }^{24}$.

Niepodważalność szacunku i zaufania, jakim całe praktycznie przedstawione w powieści środowisko otacza Bezouška, powoduje, że wszyscy chętnie poddają się jego autorytetowi, przyjmują oferowaną im z jego strony pomoc i ,prawidłowo" odczytują paraboliczność snutych przez niego opowieści ${ }^{25}$.

Nie tylko bowiem tytułowy bohater dysponuje w tym środowisku ukształtowanym przez wspólnotę wiejską „kapitałem kulturowym”, systemem przekonań aksjologicznych, doświadczeniem i znajomością tekstów folkloru, których skądinąd pamięć protagonisty jest niewyczerpalną skarbnicą. Inne powieściowe postaci również legitymują się tu, mniej lub bardziej odległym, ludowym rodowodem. Z tego punktu widzenia losy rodziny Bezoušków uznać wypada za modelowe czy egzemplaryczne ujęcie czeskiego awansu międzypokoleniowego zarówno w obrębie odrodzeniowego kultu ludowego pochodzenia rodzimej inteligencji, określającego rudymentarne wyznaczniki jej kolektywnej i indywidualnej tożsamości ${ }^{26}$, jak i w ramach rzeczywistej struktury społecznej tworzącego się na nowo narodu ${ }^{27}$.

Fascynacja mieszczan poglądami i postawą starego wieśniaka, uosabiającego w ich oczach wszystkie przypisywane ludowej etyce i sposobowi postrzegania i interpretowania świata cnoty i zalety, stanowi najpełniejszą być może po $B a$ bičce i bez wątpienia wchodzącą z dziełem Němcovej w intertekstualny dialog,

${ }^{24}$ J. Ługowska, op. cit., s. 263.

${ }^{25}$ Por.: „W literaturoznawczej, a także społeczno-kulturowej refleksji nad rolą starca jako seniora rodu, któremu powierzona zostaje - szczególnie wyeksponowana w kulturze pedagogicznej wieku XIX — piecza nad patriotycznym wychowaniem wnuków, uwzględnić więc niewątpliwie trzeba również kwestie związane ze sposobami posługiwania się przez ówczesną wspólnotę komunikacyjną tekstami społecznie ważnymi, o istotnej funkcji modelującej. Odnotowana [...] »nałogowa chęć opowiadania« objawiana przez nestora rodu, spotykająca się zawsze z pozytywnym odzewem ze strony młodego pokolenia [...], dowodzi, że właśnie model komunikacji oparty na słowie mówionym, a także mechanizm bezpośredniego przekazu międzypokoleniowego, oparty na »naturalnej« niejako przewadze i autorytecie ludzi starszych, stworzyły szczególną szansę dowartościowania społecznej roli dziadka jako depozytariusza rodzinnej, często również narodowej tradycji, którego wiedza i gromadzone przez długie lata doświadczenie służyć mogą kolejnym pokoleniom". Ibidem, s. 263-264.

${ }^{26}$ Por. V. Macura, Chaloupka..., s. 50, 52.

27 Por.: „Patricijský svět buržoazie nebyl zpravidla český a drobná buržoazie a inteligence, jakož i vznikající proletariát městský přicházel většinou z venkova a byl svým původem, vzpomínkami, obsahem citových vztahů i životním stylem stále ještě zakotven na venkově a jeho tradicích (F. Vodička, Počátky krásné prózy novočeské, Praha 1948, s. 261); Nicméně právě selství bylo v obrození [...] jedinou reálnou bází národní existence [...]. Podnes je náš typologický habitus zhola nemyslitelný bez tohoto zázemí i tohoto pozadí. Ne pouze proto, že v druhém či třetím kolenu vlastně všichni pocházíme viceméně ze selského rodu, že selská tradice je pro většinu z nás živou součástí osobních a rodinných tradic, ale proto, že české selství se vší svou výjimečností, jedinečností, ba ojedinělostí skutečně vytvářelo naše základní životní podmínky, že bylo sociálně i mravně normotvorné. J. Jedlička, op. cit., s. 39. 
apoteozę spokojnej i godnej starości, odnajdującej swe przeznaczenie w przekazywaniu zdobytego doświadczenia następnym generacjom. Nie zawsze jednak wiek podeszły zasługuje w powieści Raisa na respekt i wpisywany bywa w obręb gloryfikowanych atrybutów czeskości. Estyma, która otacza Bezouška, nie dotyczy tu wszystkich - licznych skądinąd - postaci powieściowych starców. Nie sama bowiem starość decyduje w ujęciu pisarza o prawie do szacunku i aprobaty. O wiele większą rolę odgrywa w tym przypadku przeszłość poszczególnych bohaterów, programująca niejako jakość schyłku ich życia. W powieściowej, wyraźnie bazującej na fatalistycznej koncepcji conditio humana, przestrzeni etycznej każde dobro zostaje zrekompensowane, zło natomiast nieuchronnie zwraca się przeciwko swojemu sprawcy, gdyż panuje tu starotestamentowa niemal, a pochodząca z romantycznej jeszcze wizji ludowej moralności zasada bezwarunkowej odpowiedniości winy i kary. Ta przełamująca nieco nakazy realistycznej reprezentacji rzeczywistości, a oparta na przeświadczeniu o realnej ingerencji sfery transcendentnej w przestrzeni doczesności i o bezwzględnej mocy obowiązywania Boskich praw interpretacja świata znajduje pełne potwierdzenie w porządku fabularnym powieści. Przypadkowe spotkanie w parku sparaliżowanego, przykutego do inwalidzkiego wózka i zdanego na łaskę służby byłego zarządcy z rodzimej wsi bohatera, a przede wszystkim opowieść protagonisty o nim czy raczej o krzywdzie wyrządzonej przez niego własnej rodzinie, w pierwszym rzędzie staje się przede wszystkim pretekstem do snucia analogii między postępowaniem owego urzędnika a niezrozumiałym uporem, z jakim teść syna Bezouška nie godzi się na małżeństwo swej młodszej córki z ubogim studentem i w efekcie odgrywa kluczową rolę dla konstrukcji tekstu, pozwalając na szczęśliwe rozwiązanie romansowego wątku fabuły. Przestroga płynąca z tej parabolicznie potraktowanej historii ma jednak znaczenie szersze i w projektowaniu powieściowego etosu fundamentalne, a zasadza się na twierdzeniu, że starość samotna i pozbawiona oparcia w życzliwości i opiece bliskich nie rodzi się bez przyczyny — stanowi raczej nieuniknioną konsekwencję nieodkupionych czy niezadośćuczynionych win, traktowanych w chrześcijańskim duchu pojmowanego grzechu. Jak bowiem w sentencjonalnym skrócie komentuje fizyczne zniedołężnienie i społeczną degradację spotkanego zarządcy Bezoušek: „I je to, je, bože, na tom světě! Kdyby tak člověk napřed věděl, co a jak bude, to by mnohý chodil zticha a nestavěl se na paty" 28 .

Bliski absolutnej stanowczości kantowskiego imperatywu moralnego wymiar kierowanych pod adresem ludzkich działań wymogów i norm etycznych góruje zatem w Raisowskim dziele nad wszelkimi egzystencjalnymi, ekonomicznymi czy biologicznymi uwarunkowaniami, wpisując biografię ludzką w metafizyczny porządek, którego rzecznikiem pisarz czyni swego najbardziej znanego bohatera.

${ }^{28}$ K.V. Rais, op. cit., s. 214. 


\section{Bibliografia}

Bauer M., Souvislosti labyrintu. Kodifikace ideologicko-estetické normy v české literature 50. let 20. století, Praha 2009.

Czyżak A., Na starość. Szkice o literaturze przełomu tysiacleci, Poznań 2011.

Czyżak A., Starość i literatura - strategie wykluczenia, [w:] Dwudziestowieczność, red. M. Dąbrowski, T. Wójcik, Warszawa 2004.

Dragun G., „Chcę być stara, dojrzała kobieta”. Afirmacja dojrzałości w prozie Izabeli Filipiak i Olgi Tokarczuk, [w:] Egzystencjalne doświadczenie starości w literaturze, red. A. Gleń, I. Jokiel, M. Szladowski, Opole 2008.

Filipowicz M., Urodzić naród. Z problematyki czeskiej i słowackiej literatury kobiecej II połowy XIX wieku, Warszawa 2008.

Fořt B., Fikční světy české realistické prózy, Praha 2014.

Jedlička J., České typy a jiné eseje, Praha 2009

Kaczmarek M., O dobrodziejstwach pamięci starego człowieka. Oblicza starczej pamięci w wybranych tekstach literackich, [w:] Egzystencjalne doświadczenie starości w literaturze, red.

A. Gleń, Opole 2008.

Ługowska J., „Dziadunio” jako figura nadawcy i rola narracyjna w literaturze przeznaczonej dla młodego odbiorcy, [w:] Egzystencjalne doświadczenie starości w literaturze, red. A. Gleń, Opole 2008.

Macura V., Český sen, Praha 1998.

Macura V., Chaloupka — projekt idyly, [w:] Poetika mist, red. D. Hodrová, Praha 1997.

Macura V., Znamení zrodu. České národní obrozeni jako kulturní typ, Jinočany 1995.

Rais K. V., Pantáta Bezoušek, Praha 1981.

Rak J., Exotismus doma aneb venkov versus město, [w:] Cizi, jiné, exotické v české kultuře 19. století, red. K. Bláhová, V. Petrbok, Praha 2008.

Seifert J., Ruce Venušiny (výbor z poezie), Praha 1998.

Štěpánek V., Karel Václav Rais, [w:] K.V. Rais, Pantáta Bezoušek, Praha 1981.

Vodička F., Počátky krásné prózy novočeské, Praha 1948.

\section{Between ennoblement and depreciation. Ideological codes of senility in the ninenteenth century Czech literature (the case of Karel Václav Rais)}

\section{Summary}

Interpretations of senility change in time. Successive periods of culture create codes of its description and evaluation on their own. Czech literature which from the very beginning of the nineteenth century was connected with the communication of the ideological, social and political senses of the National Revival and which was treated as the most important instrument of projecting and implementing the great collective ideas, was also directed into including these ideas in all fields of life. The glorification of senility, either as the existential category or the synonym of experience and wisdom was for the first time demonstrated in Božena Němcová's novel Babička. The high status of this masterpiece caused the many returns of the category of senility in Czech fiction. One of them is Karel Václav Rais prose Pantáta Bezoušek which initiates the discussion on the actual function of the old men/women in contemporary Czech society.

Keywords: experience, tradition, memory, ideology, National Revival

Slavica Wratislaviensia 163, 2016

(C) for this edition by CNS 


\section{Mezi nobilitací a depreciací. Ideologické kódy vnímání stáŕí v české literatuře (případ Karla Václava Raise)}

Obsah

Vnímání stáří se mění v čase. Každá následující epocha vytváří vlastní kódy jeho popisu a valorizace. Česká literatura, které je od 19. století přisuzována funkce nositelky ideologických/ politických/společenských obsahů a jsou jí určovány úkoly (nezř́íka klíčové) v programování a realizaci velkých společenských projektů, usilovala o podřízení všech oblastí života těmto projektům. Apoteózu stáŕí — jako důležité existencionální kategorie a zároveň synonyma zkušenosti a moudrosti — vykonala v této literatuře, jak známo, poprvé Božena Němcová v románu Babička. Nepochybná autorita tohoto románu způsobila, že tato kategorie byla četně a s chutí využíváná, přičemž jí byly přisuzovány rozmanité funkce s využitím různých valorizačních nástrojů. Karel Václav Rais se naprríklad v románu Pantáta Bezoušek (1894) titulní postavou „moudrého venkovského starce" vrací k diskuzi na téma nejdůležitějších identitních předpokladů Národního obrození a ověřuje jejich aktuálnost v moderní společenské realitě konce 19. století.

Kličová slova: zkušenost, tradice, pamět', ideologie, Národní obrození 